\title{
Validating the inhibitory effects of $D$ - and L-serine on the enzyme activity of D-3-phosphoglycerate dehydrogenases that are purified from Pseudomonas aeruginosa, Escherichia coli and human colon
}

\author{
Jun Okuda*, Syouya Nagata, Masashi Yasuda and Chigusa Suezawa
}

\begin{abstract}
Background: We previously demonstrated that the serA gene is associated with bacterial pathogenicity, including bacterial penetration through the Caco-2 cell monolayers, bacterial motility, bacterial adherence, and fly mortality. L-Serine is known to inhibit the D-3-phosphoglycerate dehydrogenase (PGDH) activity of the SerA protein, and it significantly reduced the bacterial pathogenicity as described above. We also demonstrated that in a PGDH assay using crude extracts isolated from overnight cultures of E. coli overexpressing the P. aeruginosa serA gene, L-serine inhibited the PGDH activity of the SerA protein. The basal PGDH activity of the negative control strain was high, presumably due to contamination of unknown proteins in the crude extracts. Therefore, to further confirm the direct inhibition of PGDH activity of $P$. aeruginosa SerA by L-serine, we purified and characterized the PGDH from $P$. aeruginosa and compared it with the previously characterized PGDHs from E. coli, and the human colon as controls.

Results: Optimum pH and ionic strength of the purified PGDHs were different depending on the three species; optimal activity of P. aeruginosa PGDH was at pH 7.5 with 50-100 mM Tris- $\mathrm{HCl}$, E. coli PGDH was at pH 8.5 with 100$200 \mathrm{mM}$ Tris- $\mathrm{HCl}$, and human PGDH was at pH 9.0 with 100-200 mM Tris-HCl. The addition of L-serine reduced the activity of PGDH from $P$. aeruginosa and $E$. coli, but not the PGDH from human colon. The median inhibitory concentration $\left(I C_{50}\right)$ of L-serine was $630 \mu \mathrm{M}$ for P. aeruginosa and $250 \mu \mathrm{M}$ for $E$. coli, while $I C_{50}$ of D-serine was much higher than that of L-serine; $76 \mathrm{mM}$ in P. aeruginosa PGDH and $45 \mathrm{mM}$ in E. coli PGDH.

Conclusions: These results suggest that L-serine significantly repressed $P$. aeruginosa pathogenicity through direct inhibition of the PGDH activity, but was not able to inhibit the human PGDH activity. Oral administration of L-serine to compromised hosts might interfere with bacterial translocation and prevent gut-derived sepsis caused by P. aeruginosa through inhibition of the function of the serA gene product.
\end{abstract}

Keywords: serA, D-3-phosphoglycerate dehydrogenase, P. aeruginosa, Human colon, D- and L-serine, Bacterial translocation, Gut-derived sepsis

*Correspondence: okuda@chs.pref.kagawa.jp

Division of Microbiology, Department of Medical Technology, Kagawa

Prefectural University of Health Sciences, Kagawa, Japan 


\section{Background}

Pseudomonas aeruginosa is the causative agent of various opportunistic infections, including gut-derived sepsis. We previously demonstrated that the $\operatorname{ser} A$ gene is associated with the bacterial pathogenicity, and has a role in promoting the bacterial penetration through the Caco-2 cell monolayers, which was accompanied by decreased swimming and swarming motility, bacterial adherence, and fly mortality [1]. Further, we previously investigated whether L-serine, which is known to inhibit the D-3-phosphoglycerate dehydrogenase (PGDH) activity of the SerA protein, significantly reduces the known phenotypes associated with bacterial pathogenicity. Consequently, the addition of L-serine was found to significantly reduce the phenotypes associated with the bacterial pathogenicity, including bacterial penetration through Caco-2 cell monolayers, bacterial swimming and swarming motility, bacterial adherence, and fly mortality [1]. Furthermore, we show that in a PGDH assay using crude extracts that were isolated from overnight cultures of $E$. coli overexpressing the $P$. aeruginosa serA gene, L-serine directly inhibited the PGDH activity of the SerA protein. The background PGDH activity of the negative control strain was high, presumably due to contaminated proteins in the crude extracts. Therefore, to further confirm the direct inhibition of PGDH activity of $P$. aeruginosa SerA by L-serine, we purified the PGDH from $P$. aeruginosa using the glutathione S-transferase (GST) fusion protein system which is used for high-level expression and efficient purification of recombinant proteins.

As described in detail previously [2, 3], the serA gene encodes the D-3-phosphoglycerate dehydrogenase (PGDH) and catalyzes the first step in serine synthesis by utilizing $\mathrm{NAD}^{+}$as a cofactor in Escherichia coli. It is known that the activity of PGDHs derived from certain bacterial species including $E$. coli, can be allosterically inhibited by L-serine, the end product of the serine synthesis pathway, due to a conformational change in the three-dimensional structure of PGDH upon binding of L-serine [2, 3]. On the other hand, the activity of PGDHs isolated from rat and chicken livers appears not to be influenced by the addition of L-serine [4-6]. As described in detail previously $[7,8]$, this difference in the inhibitory effects of L-serine on the PGDH activity among these species seems to be dependent on the difference in the amino acid sequence and the three-dimensional structure of each PGDH. PGDHs consists of at least three different structural motifs that have been classified as types I, II, and III as described in detail previously [7-10]. As described in detail previously $[6-8,10]$, the PGDHs from certain bacteria including E. coli, $P$. aeruginosa, $H$. influenza, and the simple eukaryotes such as yeast, Leishmania, and Neurospora, retain the type II motif, which contains three distinct domains called the cofactor or nucleotide-binding domain, the substrate-binding domain, and the $\mathrm{C}$-terminal regulatory or the serine binding domain. The C-terminal regulatory or the serine binding domain is also called as the ACT (aspartate kinase-chorismate mutase-tyrA prephenate dehydrogenase) domain and is responsible for $\mathrm{L}$-serine binding and the regulation of PGDH activity; in E. coli PGDH, there are critical amino acid residues which are needed for L-serine binding as described in detail previously [7, 8]. Other bacteria, including Mycobacterium tuberculosis, Bacillus subtilis, and the higher eukaryotes, including mouse, rat, and human, possess the type I motif which harbors a large polypeptide insertion, which is called as ASB (allosteric substrate binding) domain, in the C-terminal fragment which follows the substrate binding domain as described in detail previously [7, 8]. Some organisms, including Pyrococcus, Rhodopseudomonas, Clostridium, Entamoeba histolytica, Bacteroides fragilis, and Porphyromonas gingivalis, have the type III motif which lacks the $\mathrm{C}$-terminal regulatory domain as described in detail previously $[7,8]$. Furthermore, there are two forms of the type III motif depending on whether lysine (type $\mathrm{K}$ ) or histidine (type $\mathrm{H}$ ) exists at the active site as described in detail previously $[7,8,10]$.

In the present study, we performed the purification and characterization of the PGDH from P. aeruginosa PAO1 strain by exploiting the GST fusion protein system as there is no report yet available on the characterization of the $P$. aeruginosa PGDH. Furthermore, we determined the median inhibitory concentration $\left(\mathrm{IC}_{50}\right)$ of $\mathrm{D}$ - and L-serine against the purified PGDH isolated from the $P$. aeruginosa serA gene.

\section{Materials and methods Bacterial strains}

Escherichia coli DH5 $\alpha$ strain was purchased from TOYOBO, Japan. E. coli BL21 strain was used to express the GST fusion protein and was purchased from GE Healthcare, Japan [11].

\section{Sequence homology}

All sequences used in this study were obtained from the National Center for Biotechnology Information (https ://www.ncbi.nlm.nih.gov/). Sequence alignments were performed using the ClustalW (http://clustalw.ddbj.nig. ac.jp/) and the EMBOSS Needle (https://www.ebi.ac.uk/ Tools/psa/emboss_needle/).

\section{Cloning of $P$. aeruginosa serA gene}

To construct the plasmid used for the expression of glutathione $S$-transferase (GST) $-P$. aeruginosa PGDH fusion protein, BamHI-XhoI fragment 
carrying $P$. aeruginosa serA ORF was amplified by LA Taq DNA polymerase (TAKARA) under conditions recommended in the manufacturer's protocol with 5-PA-serA-BamHI-ATG-356477 (5'-GAGAGGATC CATGAGCAAGACCTCTCTCGA-3) and 3-PA-serAXho1-end-355248 primers (5'-GAGACTCGAGTT AGAACAGCACGCGGCTAC-3); this insert corresponds to the nucleotides 355248 to 356477 in the PAO1 genome sequence (https://www.pseudomonas.com). The BamHI-XhoI fragment was ligated into the BamHI-XhoI site of pGEX-6P-1 (GE Healthcare) [12], and the resultant plasmid (pGEX-6P-1-PserA) was transformed into E. coli DH5 $\alpha$. The plasmid was isolated from E. coli DH5 $\alpha$ and was transformed into $E$. coli BL21. The resultant transformant was designated as BL21 (pGEX-6P-1-PserA).

\section{Cloning of $E$. coli serA gene}

To construct the plasmid used for the expression of the GST-E. coli PGDH fusion protein, SmaI-XhoI fragment carrying the $E$. coli serA ORF was amplified by LA Taq DNA polymerase (TAKARA) under conditions recommended in the manufacturer's protocol with 5-ECWserA-Sma1-ATG-2966687 (5'-GAGACCCGGGTATGG CAAAGGTATCGCTGG3) and 3-ECW-serA-Xho1end-2965455 (5'-GAGACTCGAGTTAGTACAGCA GACGGGCGC-3') primers; this insert corresponds to the nucleotides 2965455 to 2966687 in the Escherichia coli strain K-12 substrain W3110 substrain ZK126 genome (https://www.ncbi.nlm.nih.gov). The SmaI-XhoI fragment was ligated into the SmaI-XhoI site of pGEX6P-1, and the resultant plasmid (pGEX-6P-1-EserA) was transformed into E. coli $\mathrm{DH} 5 \alpha$. The plasmid was isolated from E. coli $\mathrm{DH} 5 \alpha$ and was transformed into $E$. coli BL21. The resultant transformant was designated as BL21 (pGEX-6P-1-EserA).

\section{Cloning of the human serA gene}

To construct the plasmid used for the expression of the GST-human PGDH fusion protein, BamHI-XhoI fragment carrying the human serA ORF was amplified by LA Taq DNA polymerase (TAKARA) with primers 5-Human-serA-BamH1-ATG (5'-GAGAGGATC CATGGCTTTTGCAAATCTGCG-3) and 3-HumanserA-Xho1-end (5'-GAGACTCGAGTTAGAAGTGGA ACTGGAAGG-3'); this insert corresponds to nucleotides 137-1742 in the Homo sapiens phosphoglycerate dehydrogenase mRNA (cDNA clone MGC:18226 IMAGE:4156703) (https://www.ncbi.nlm.nih.gov).

Human Colon Plasmid cDNA library (Stratagene, \#982261) was amplified again on solid medium plate, and plasmid DNA was purified from the amplified library with a plasmid extraction kit (Qiagen).
PCR was carried out in a $50 \mu \mathrm{L}$ reaction mix containing $200 \mathrm{mM}$ dNTPs (each), $315 \mathrm{ng}$ of human colon plasmid DNA, $0.2 \mathrm{mM}$ primers (each), $5 \mu \mathrm{L}$ of Takara LA PCR buffer, $2.5 \mathrm{mM} \mathrm{MgCl}_{2}$, and $5 \mathrm{U}$ of Takara LA Taq polymerase. The protocol was performed as follows: 2 min at $94{ }^{\circ} \mathrm{C}$ followed by 35 cycles of $94{ }^{\circ} \mathrm{C}$ for $30 \mathrm{~s}, 58.6{ }^{\circ} \mathrm{C}$ for $30 \mathrm{~s}$, and $72{ }^{\circ} \mathrm{C}$ for $2 \mathrm{~min}$, and an extension step at $72{ }^{\circ} \mathrm{C}$ for $8 \mathrm{~min}$. PCR product of amplicon of $1.6 \mathrm{~kb}$ was cloned into pGEMeasy T-vector (Promega), the resultant plasmid (pGEM-HserA) was transformed into E. coli $\mathrm{DH} 5 \alpha$. The plasmid was isolated from E. coli DH5 $\alpha$, and then digested with BamHI and XhoI and the digested fragment carrying the human serA ORF was ligated into the BamHI-XhoI site of pGEX-6P-1, and the resultant plasmid (pGEX-6P-1-HserA) was transformed into E. coli $\mathrm{DH} 5 \alpha$. The plasmid was isolated from $E$. coli $\mathrm{DH} 5 \alpha$ and transformed into E. coli BL21. The resultant transformant was designated as BL21 (pGEX-6P-1-HserA).

\section{Purification of the recombinant PGDHs}

The recombinant PGDHs were isolated from the BL21 (pGEX-6P-1-PserA), BL21 (pGEX-6P-1-EserA) or BL21 (pGEX-6P-1-HserA) culture as described below. A $20 \mathrm{~mL}$ aliquot of BL21 (pGEX-6P-1-PserA), BL21 (pGEX-6P1-EserA) or BL21 (pGEX-6P-1-HserA) culture grown in LB broth supplemented with $100 \mu \mathrm{g} / \mathrm{mL}$ of ampicillin was inoculated into $200 \mathrm{~mL}$ of fresh LB broth supplemented with $100 \mu \mathrm{g} / \mathrm{mL}$ of ampicillin, incubated at $37^{\circ} \mathrm{C}$ for $3 \mathrm{~h}$. PGDH expression was then induced by the addition of $2 \mathrm{mM}$ isopropyl- $\beta$-D-thiogalactopyranoside and then incubated at $37{ }^{\circ} \mathrm{C}$ for another $1 \mathrm{~h}$. The bacterial cells were harvested by centrifugation at $4000 \times g$ for $5 \mathrm{~min}$, and the bacterial pellet was resuspended in $12 \mathrm{~mL}$ of $1 \mathrm{X}$ PBS. After the addition of lysozyme $(0.91 \mathrm{mg} / \mathrm{mL})$, the cells were disrupted by sonication for $150 \mathrm{~s}$. After the cell debris was removed by centrifugation at $20,000 \times g$ for $10 \mathrm{~min}, 400 \mu \mathrm{L}$ of $50 \%$ slurry of GST-Accept (Nakalai Tesque) was added to the supernatant. After mixing with rotation for $1 \mathrm{~h}$, the cell lysate was centrifuged and the GST-bound proteins were collected. The resulting GST-Accept (containing GST-protein) was washed five times with precision buffer $(100 \mathrm{mM}$ Tris- $\mathrm{HCl} \mathrm{pH} 7.5$, $150 \mathrm{mM} \mathrm{NaCl}, 1 \mathrm{mM}$ EDTA, $1 \mathrm{mM}$ DTT) and was finally resuspended in $400 \mu \mathrm{L}$ of the precision buffer. After addition of precision proteinase ( 30 units $/ \mathrm{mL}$ ), the tube was mixed by rotation for $15 \mathrm{~h}$ and the supernatant containing the PGDH was collected by centrifugation at $4000 \times g$ for $1 \mathrm{~min}$. The purified PGDH was the used for further analysis including the PGDH activity assay. The amount of protein was measured by TaKaRa Bradford Protein Assay Kit (Takara-bio, Japan). The purified PGDH was 
applied to 12\% SDS-PAGE, after which the proteins were stained using Rapid Stain CBB Kit (Nacalai Tesque).

\section{PGDH activity assay}

PGDH activity assay was carried out as described previously [13] with a modification. Briefly, PGDH activity was measured by measuring an increase in absorbance at $339 \mathrm{~nm}$ in the presence of NAD (Nakalai Tesque) and 3-phosphoglycerate (3PG; Sigma-Aldrich, USA). The assays were performed in triplicate and contained the reaction mixture with $100 \mathrm{mM}$ Tris- $\mathrm{HCl}$ buffer $(P$. aeruginosa PGDH: $\mathrm{pH} 7.5$, E. coli PGDH: $\mathrm{pH}$ 8.5, human PGDH: pH 9.0) containing 5 mM EDTA (Wako, Japan), $1 \mathrm{mM}$ DTT (Wako), $10 \mathrm{mM}$ hydrazine (Wako) and $2 \mathrm{mg} /$ mL NAD. The reaction was started with $15 \mathrm{mM} 3$-phosphoglycerate and the formation of NADH was measured spectrophotometrically at $339 \mathrm{~nm}$. The enzyme activity (unit per mg protein) was calculated by following the enzyme unit reported previously $[14,15]$.

\section{Inhibition of PGDH by L-serine or D-serine}

PGDH activity assay was performed in the presence of the designated concentration of $\mathrm{L}$-serine or D-serine to evaluate $50 \%$ inhibitory concentration $\left(\mathrm{IC}_{50}\right)$ of $\mathrm{L}$-serine or D-serine against PGDH. The $\mathrm{IC}_{50}$ was determined as the concentration of $\mathrm{L}$-serine or $\mathrm{D}$-serine that reduced the PGDH activity by $50 \%$ as compared to the PGDH activity without the inhibitor.

\section{Statistical analysis}

Statistical analysis was performed using a two-tailed $t$ test.

\section{Results}

\section{Sequence homology}

Figure 1 shows the amino acid sequence alignments of PGDHs from three species, P. aeruginosa, E. coli, and human. The similarity score is $64 \%$, and the identity score is $81 \%$ between $P$. aeruginosa and $E$. coli. The similarity score is $24 \%$, and the identity score is $37 \%$ between $P$. aeruginosa and human. The similarity score is $23 \%$, and the identity score is $35 \%$ between $E$. coli and human. The human PGDH sequence is longer than the $P$. aeruginosa and $E$. coli PGDHs because of the presence of the insertion sequence (amino acids residues 348-394) in Fig. 1.

\section{SDS-PAGE analysis of the purified PGDHs}

The result of SDS-PAGE analysis of the three purified PGDHs is shown in Fig. 2. PGDHs of the three species were purified to the level of a single band without any visible contaminating band. The $P$. aeruginosa and the human PGDH bands appeared at the molecular weight size $(44 \mathrm{kDa}$ and $56 \mathrm{kDa})$ that was deduced from their serA gene sequences, while the E. coli PGDH band appeared at a slightly higher than the expected molecular weight size $(48 \mathrm{kDa})$ predicted from its $\operatorname{ser} A$ gene sequence.

\section{Optimum $\mathrm{pH}$ and ionic strength}

PGDHs activity shows different optimum $\mathrm{pH}$ and ionic strength depending on their origin species (Figs. 3, 4). As shown in Fig. 3, the optimal activity of $P$ aeruginosa PGDH was detected between $\mathrm{pH} 7.5$ and $\mathrm{pH} 8.0$, while that of both E. coli PGDH and human PGDH was between $\mathrm{pH} 8.5$ and $\mathrm{pH}$ 9.0. Also, as shown in Fig. 4, the optimal activity of $P$. aeruginosa PGDH was observed in 50 and $100 \mathrm{mM}$ Tris $-\mathrm{HCl}$ buffer, while that of both $E$. coli PGDH and human PGDH was detected in 100 and $200 \mathrm{mM}$ Tris- $\mathrm{HCl}$ buffer.

\section{Inhibitory effect of L-serine on PGDH activity}

As shown in Fig. 5, the PGDH activity of $P$. aeruginosa was inhibited in a dose-dependent manner by 240 $960 \mu \mathrm{M}$ L-serine $(\mathrm{P}<0.05)$ and that of $E$. coli was also inhibited in a dose-dependent manner by $60-960 \mu \mathrm{M}$ L-serine $(\mathrm{P}<0.05)$. As described previously [2], the $50 \%$ inhibitory concentration $\left(\mathrm{IC}_{50}\right)$ of $\mathrm{L}$-serine was calculated by plotting the inhibitor concentration against the percent activity of PGDH (Fig. 6). $\mathrm{IC}_{50}$ of L-serine against $P$. aeruginosa $\mathrm{PGDH}$ was $630 \mu \mathrm{M}$ and that against E. coli $\mathrm{PGDH}$ was $250 \mu \mathrm{M}$. On the other hand, human PGDH activity was not inhibited even by the addition of 100 mM L-serine (Figs. 5, 6).

\section{Inhibitory effect of D-serine on PGDH activity}

As shown in Fig. 7, the PGDH activity of both $P$. aeruginosa and $E$. coli was inhibited in a dose-dependently manner by the addition of 10 to $100 \mathrm{mM}$ D-serine $(\mathrm{P}<0.05)$. As shown in Fig. 8 , the $\mathrm{IC}_{50}$ of $\mathrm{D}$-serine against $P$. aeruginosa $\mathrm{PGDH}$ was $76 \mathrm{mM}$ and that against $E$. coli $\mathrm{PGDH}$ was $45 \mathrm{mM}$. On the other hand, the human PGDH activity was not inhibited even by the addition of 100 mM D-serine (Figs. 7, 8).

\section{Discussion}

In the present study, the optimal activity of $P$. aeruginosa PGDH was detected at between $\mathrm{pH} 7.5$ and $\mathrm{pH}$ 8.0, with a salt concentration range between 50 and $100 \mathrm{mM}$ Tris- $\mathrm{HCl}$ buffer. Since the optimum conditions for the $P$. aeruginosa PGDH activity have not been reported yet, our results would be a useful reference for the future study. Also, optimum $\mathrm{pH} 8.5$ for the $E$. 


\begin{tabular}{|c|c|c|}
\hline $\begin{array}{l}\text { PA } \\
\text { EC } \\
\text { HS }\end{array}$ & $\begin{array}{l}1 \\
1 \\
1\end{array}$ & $\begin{array}{l}\text { MSKT S LDKS KI KF L LLEGVH QNAVD TLKAAGY TN IEYLKTALSGDELKERTADAH } \\
\text { MAKVSLEKDIKIKFLLVEGVHOKALE SLRAAGY TNIEFHKGALDDEQLKESIRDAH } \\
\text { MAFANLR---KVLISDSLD PCCRK ILQDGGLVVE--KQNLSKEELIAELQDCE }\end{array}$ \\
\hline $\begin{array}{l}\text { PA } \\
\text { EC } \\
\text { HS }\end{array}$ & $\begin{array}{l}56 \\
56 \\
50\end{array}$ & 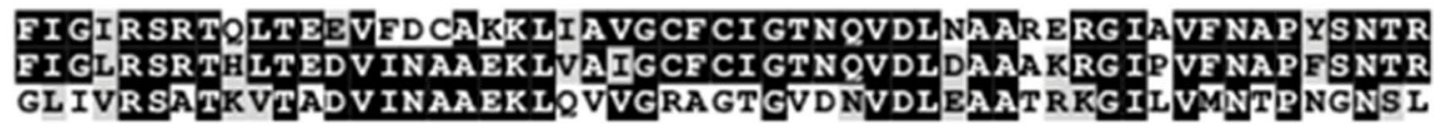 \\
\hline $\begin{array}{l}\text { PA } \\
\text { EC } \\
\text { HS }\end{array}$ & $\begin{array}{l}111 \\
111 \\
105\end{array}$ & 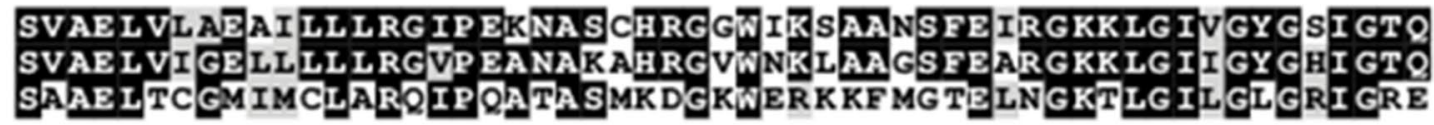 \\
\hline $\begin{array}{l}\text { PA } \\
\text { EC } \\
\text { HS }\end{array}$ & $\begin{array}{l}166 \\
166 \\
160\end{array}$ & 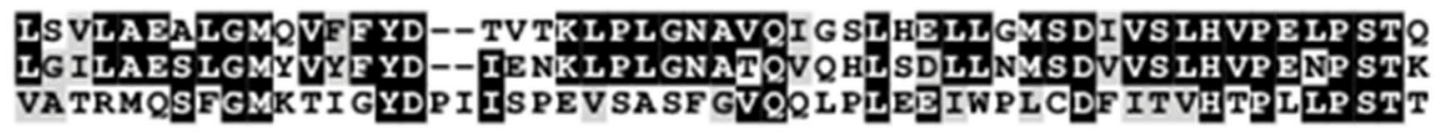 \\
\hline $\begin{array}{l}\text { PA } \\
\text { EC } \\
\text { HS }\end{array}$ & $\begin{array}{l}219 \\
219 \\
215\end{array}$ & 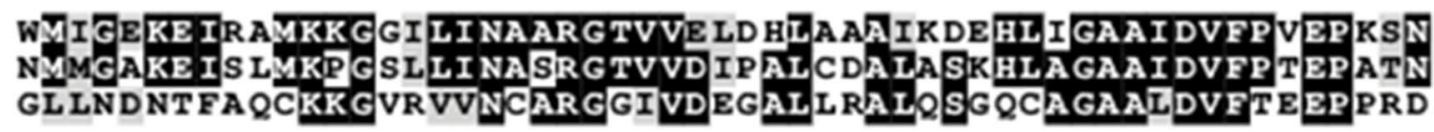 \\
\hline $\begin{array}{l}\text { PA } \\
\text { EC } \\
\text { HS }\end{array}$ & $\begin{array}{l}274 \\
274 \\
270\end{array}$ & 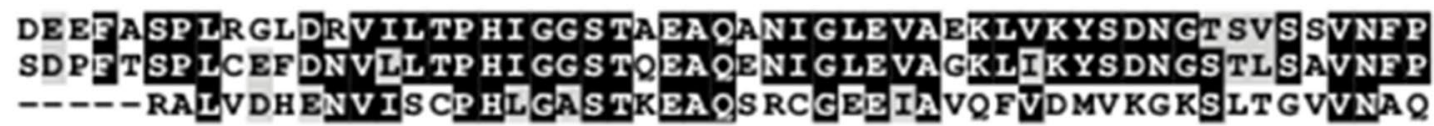 \\
\hline PA & 329 & EVALPSHPGKHRLLHI HANIPGVMSEIN- - \\
\hline & $\begin{array}{l}329 \\
320\end{array}$ & 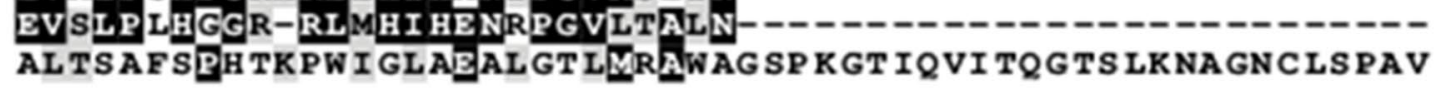 \\
\hline $\begin{array}{l}\text { PA } \\
\text { EC } \\
\text { HS }\end{array}$ & $\begin{array}{l}357 \\
356 \\
375\end{array}$ & 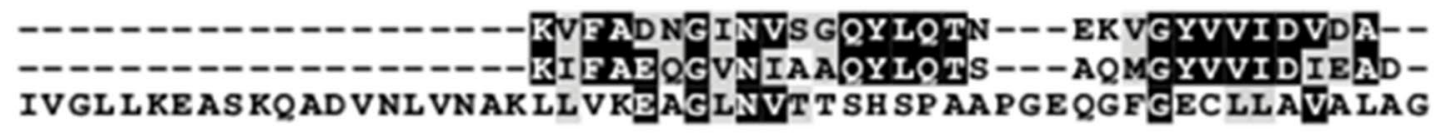 \\
\hline $\begin{array}{l}\text { PA } \\
\text { EC } \\
\text { HS }\end{array}$ & $\begin{array}{l}387 \\
387 \\
430\end{array}$ & 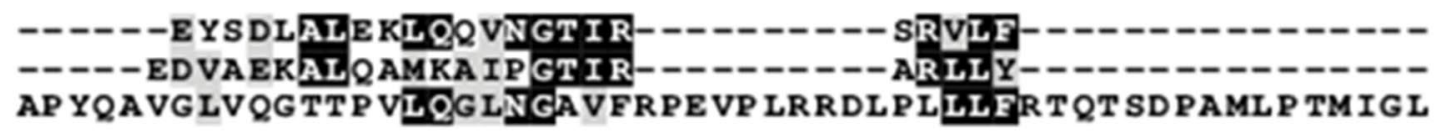 \\
\hline $\begin{array}{l}\text { PA } \\
\text { EC }\end{array}$ & & 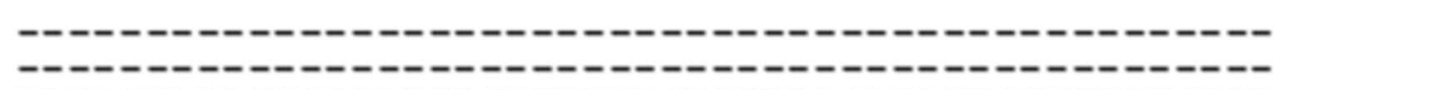 \\
\hline H S & 485 & LAEA GVRLL SY QT SLVSDGE TWHVMGI SS LLP SLEAWKQHVTEAF QF HF \\
\hline $\begin{array}{l}\text { Fig. } 1 \\
\text { sequen }\end{array}$ & uence & $\begin{array}{l}\text { alignment of PGDH from P. aeruginosa, E. coli, and human. The number denotes the position of the amino acid residue in the } \\
i \text { PGDH from a previous report by Tobey and Grant [23]. The black boxes indicate identical residues, and the gray boxes show } \\
\text { rity. Blue dots show the Pro-336-Gly-337 at the connecting region between the ACT domain and the substrate-binding domain in }\end{array}$ \\
\hline
\end{tabular}

coli PGDH determined in the present study is consistent with the previous report [6]. On the other hand, the optimum $\mathrm{pH}$ for the human colon PGDH has not been reported yet, but the activity assay of human
PGDH was carried out at $\mathrm{pH} 7.1[16,17]$. In the present study, the optimum $\mathrm{pH}$ for the human PGDH was 8.5-9.0 and is different from the $\mathrm{pH} 7.1$ used in the previous reports. There seems to be no difference in the 


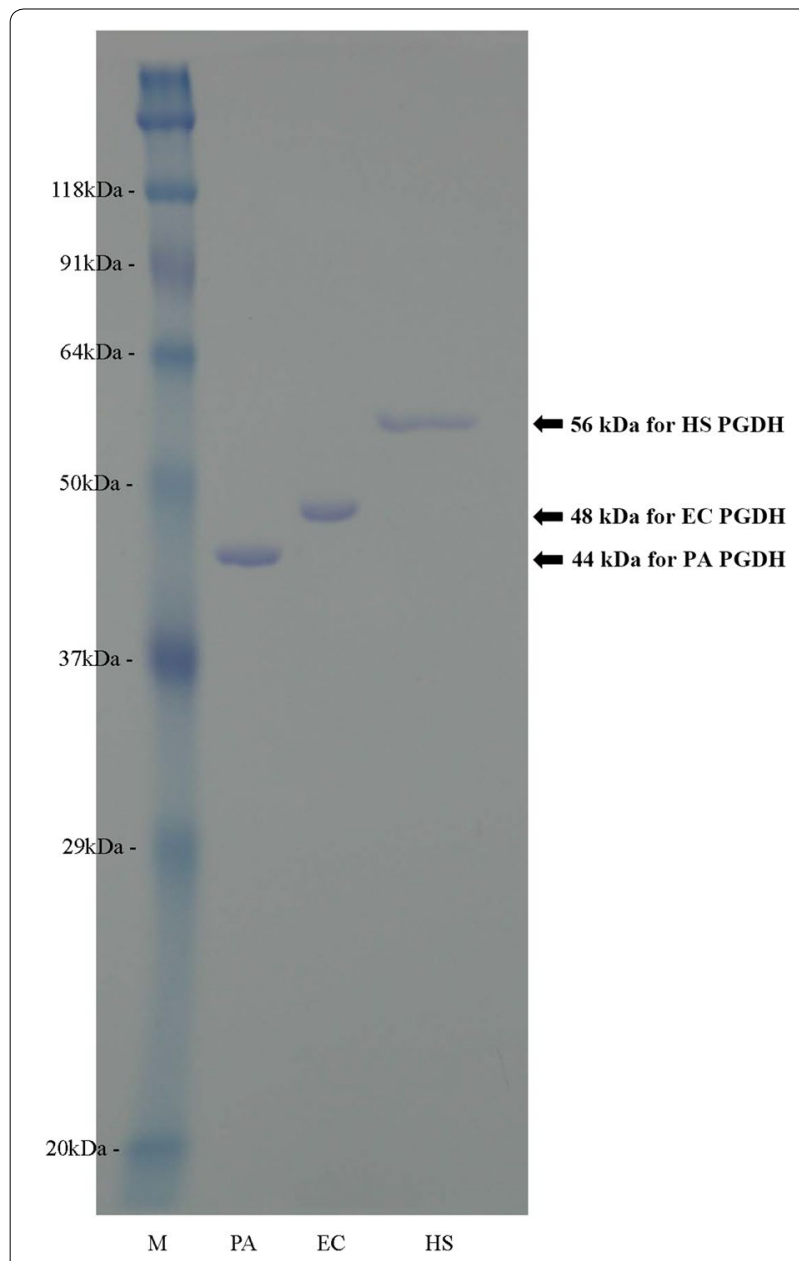

Fig. 2 SDS-PAGE analysis for the purity of the recombinant PGDHs. The purified PGDHs from three species were separated on to a 12\% SDS-PAGE followed by staining the gel with Rapid Stain CBB Kit (Nacalai Tesque). Lanes: $\mathrm{M}$, molecular mass standards indicated on the left; PA, EC, and HS show the PGDHs from P. aeruginosa, E. coli, and human colon, respectively

sequence of PGDH derived from human colon cDNA in the present study and that derived from HeLa cells and skin-derived fibroblasts reported in earlier studies including a recent review on PGDH $[8,16,17]$ (GenBank reference sequence NM_006623.3 [16] and AF006043.1 [17]). Taken together, it is suggested that the difference in optimum $\mathrm{pH}$ for the human PGDH might be due to the differences in the purification and PGDH assays rather than a difference in the tissue type from which the PGDH was isolated. In earlier studies $[16,17]$, the human PGDH activity was measured by using crude extracts prepared from transiently transfected HEK293T or BHK-21 cells expressing human PGDH and by following the previously reported methods $[18,19]$, where the reaction mixture contained
25 mM HEPES, pH7.1, in the PGDH activity assay. On the other hand, we evaluated the human PGDH activity by following the previously reported methods to determine the bacterial PGDH activity and its inhibition by L-serine [13]. Therefore, we need to investigate further for the optimum $\mathrm{pH}$ for the human PGDH by following the previously reported methods $[18,19]$ in the future study.

As described in detail previously $[7,8]$, on the basis of the results of amino acid sequence alignments shown in Fig. 1, the basal structure of $P$. aeruginosa PGDH belongs to the type II motif, as well as that of E. coli PGDH. On the other hand, human PGDH is classified as the type I motif, with the extended C-terminal region $[7,8]$. As for inhibition by L-serine is concerned, the PGDH activity of both $P$. aeruginosa and $E$. coli was inhibited in a dose-dependent manner by the addition of $\mathrm{L}$-serine, but the human PGDH activity was not inhibited even at $100 \mathrm{mM} \mathrm{L}$-serine, which further corroborated the findings of the previous studies $[7,8]$. It is hypothesized that this difference might be due to the difference in the length of the regulatory domain because in type I motif, there is an insertional ASB domain, which is not present in type II motif $[7,8]$. Further studies are needed to confirm this by utilizing a chimera type II PGDH construct from P. aeruginosa in which the regulatory domain is substituted with that of type I motif and investigate whether the PGDH activity of the chimera type II PGDH from $P$. aeruginosa is affected by the addition of $100 \mathrm{mM}$ L-serine.

On comparison of the $\mathrm{IC}_{50}$ values of $\mathrm{L}$-serine against P. aeruginosa and E. coli $\mathrm{PGDH}$, the E. coli $\mathrm{PGDH}$ showed higher sensitivity to inhibition by L-serine. As described in detail previously [20], mutations of Gly336-Gly-337, at the connecting region between the ACT domain and the substrate-binding domain, significantly reduced the inhibitory effect of L-serine on the $E$. coli PGDH activity. On the other hand, in $P$. aeruginosa PGDH, a Pro-Gly sequence was found corresponding to Gly-336-Gly-337 of E. coli PGDH at the connecting region between the ACT domain and the substratebinding domain as shown in Fig. 1. Taken together, it is predicted that the difference in $\mathrm{IC}_{50}$ values of $\mathrm{L}$-serine against $P$. aeruginosa $\mathrm{PGDH}$ and $E$. coli $\mathrm{PGDH}$ might be due to the presence of the Gly-Gly sequence in $E$. coli PGDH. However, further experiments are required to confirm this hypothesis by characterizing a mutant PGDH from $P$. aeruginosa that has a Gly-Gly sequence and examining the inhibitory effect of $\mathrm{L}$-serine on the mutant PGDH.

In the present study, we investigated the inhibitory effect of D-serine, which is an amino acid enantiomer of L-serine, against the PGDH activity. As a result, the 


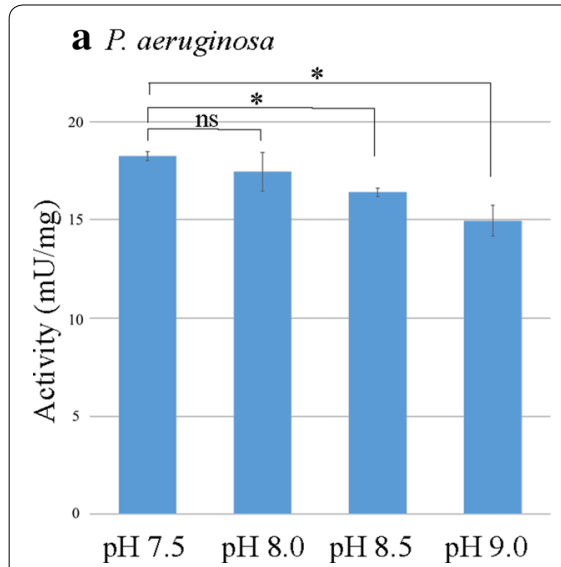

\section{b E. coli}

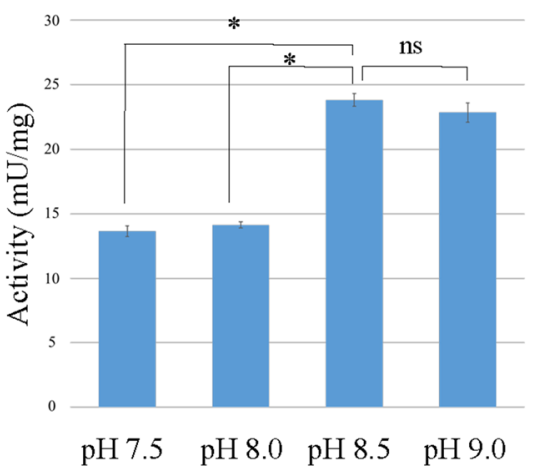

c Human

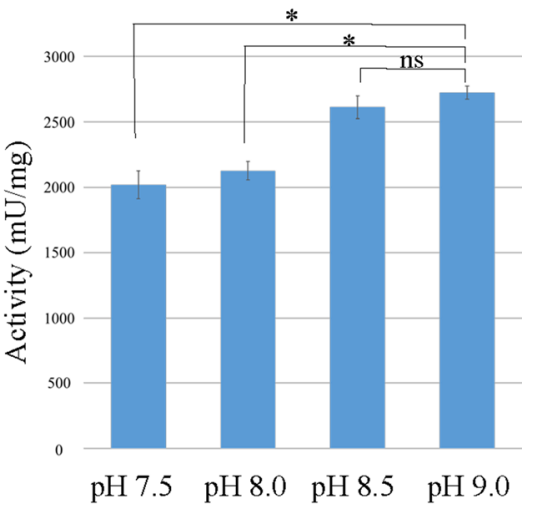

Fig. 3 Optimum pH of the purified PGDHs derived from three different species. The optimal activity $(\mathrm{mU} / \mathrm{mg})$ of each PGDH was determined by performing the PGDH activity assay in the reaction mixture containing $100 \mathrm{mM}$ Tris- $\mathrm{HCl}$ buffer at various $\mathrm{pH}$. The assay was performed in triplicate, and data being shown as the mean activity $(\mathrm{mU} / \mathrm{mg}) \pm \mathrm{SD}$. a A significant difference in the activity of $P$. aeruginosa PGDH was observed between at $\mathrm{pH} 7.5$ versus $\mathrm{pH} 8.5$ and $\mathrm{pH} 9.0$ ( ${ }^{*} \mathrm{P}<0.05$ ), but not at $\mathrm{pH} 7.5$ versus $\mathrm{pH} 8.0$ (ns: not significant, $\mathrm{P}>0.05$ ). $\mathbf{b}$ A significant difference was observed in the activity of E. coli PGDH measured at $\mathrm{pH} 8.5$ versus $\mathrm{pH} 7.5$ and $\mathrm{pH} 8.0$, ( ${ }^{*} \mathrm{P}<0.05$ ), but not at $\mathrm{pH} 8.5$ versus $\mathrm{pH} 9.0$ (ns). c A significant difference was observed in the activity of human PGDH measured at $\mathrm{pH} 9.0$ versus $\mathrm{pH} 7.5$ and $\mathrm{pH} 8.0$ ( ${ }^{*} \mathrm{P}<0.05$ ), but not at $\mathrm{pH} 8.5$ versus $\mathrm{pH} 9.0$ (ns)
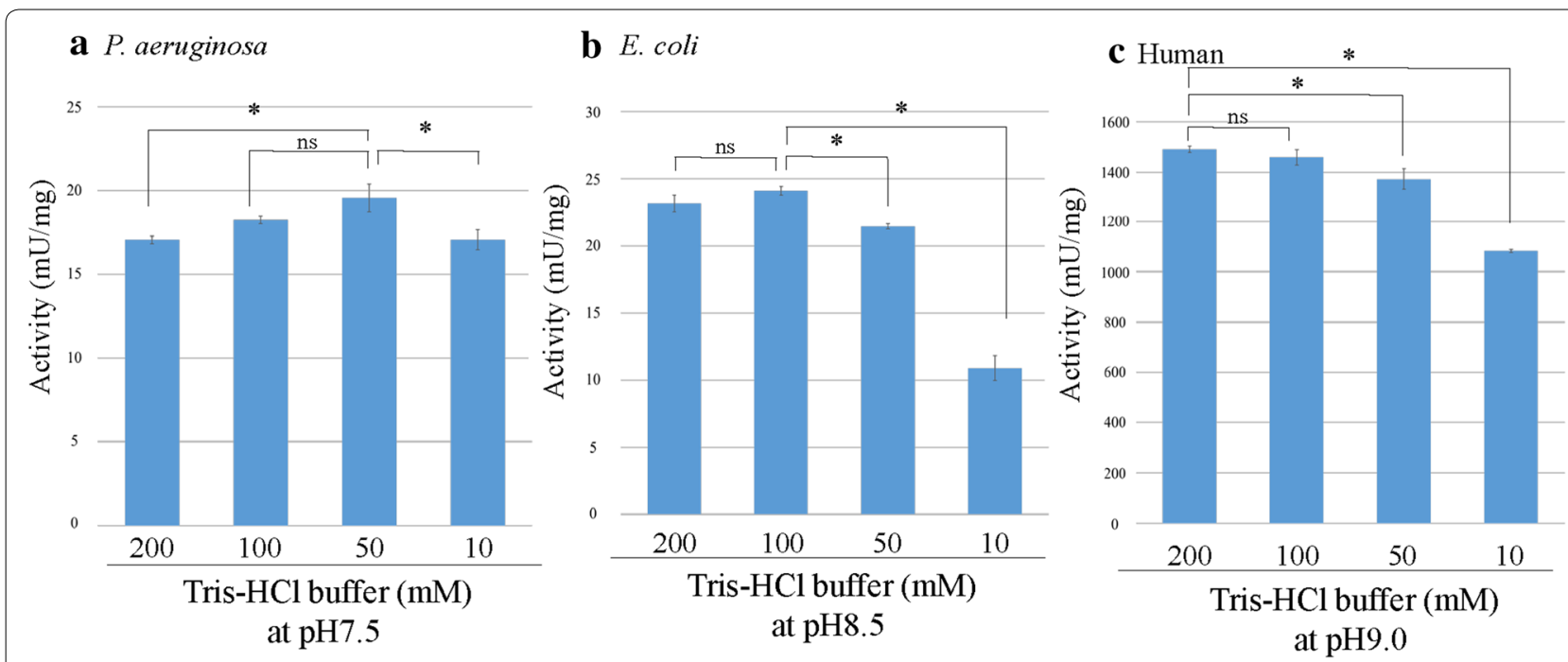

Fig. 4 The optimum ionic strength of the purified PGDHs derived from three different species. The optimal activity (mU/mg) of each PGDH was determined by performing the PGDH activity assay in the reaction mixture containing various concentrations of Tris-HCl buffer. The assay was performed in triplicate, and data being shown as the mean activity $(\mathrm{mU} / \mathrm{mg}) \pm \mathrm{SD}$. a A significant difference was observed in the $P$. aeruginosa PGDH activity measured at $50 \mathrm{mM}$ versus at $200 \mathrm{mM}$ and $10 \mathrm{mM}\left({ }^{*} \mathrm{P}<0.05\right)$, but not between P. aeruginosa PGDH activity at $50 \mathrm{mM}$ versus at $100 \mathrm{mM}$ (ns: not significant, P>0.05). b A significant difference was observed between E. coli PGDH activity at $100 \mathrm{mM}$ and that at $50 \mathrm{mM}$ and $10 \mathrm{mM}\left({ }^{*} \mathrm{P}<0.05\right)$, but not between E. coli PGDH activity at $100 \mathrm{mM}$ and that at $200 \mathrm{mM}$ (ns). c A significant difference was observed between human PGDH activity at $200 \mathrm{mM}$ and that at $50 \mathrm{mM}$ and $10 \mathrm{mM}\left({ }^{*} \mathrm{P}<0.05\right)$, but not between human PGDH activity at $200 \mathrm{mM}$ and that at $100 \mathrm{mM}$ (ns)

$\mathrm{IC}_{50}$ of D-serine was much higher than that of L-serine; $\mathrm{IC}_{50}$ of D-serine against PGDHs of $P$. aeruginosa and $E$. coli were 120- and 180-fold higher than that of $\mathrm{L}$-serine against PGDHs of $P$. aeruginosa and E. coli, respectively. As described in detail previously [21,22] earlier the inhibitory effect of other amino acids including L-serine, 

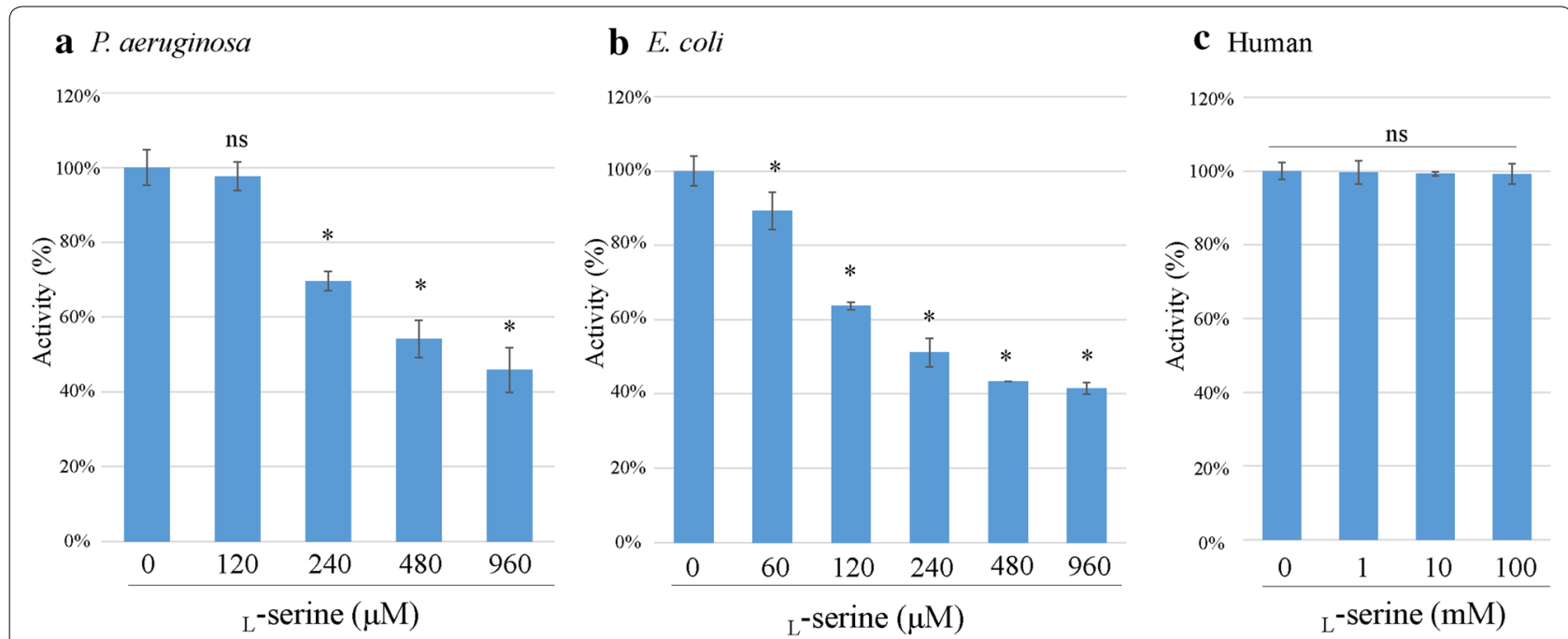

Fig. 5 Inhibitory effect of L-serine on the PGDH activity. The optimal activity $(\mathrm{mU} / \mathrm{mg})$ of each PGDH was determined by performing the assay with different concentrations of L-serine. The assay was performed in triplicate. Data are shown as the ratio of the PGDH activity in the presence of L-serine to that without L-serine and is expressed as the mean $\% \pm S D$. a Significance difference in activity was observed between $P$. aeruginosa PGDH without serine and P. aeruginosa PGDH in the presence of $240 \mathrm{mM}, 480 \mathrm{mM}$, and $960 \mathrm{mM}$ serine $\left({ }^{*} \mathrm{P}<0.05\right)$, but not between $P$. aeruginosa PGDH without serine and $P$. aeruginosa PGDH in the presence of $120 \mathrm{mM}$ serine (ns: not significant, $P>0.05$ ). $\mathbf{b}$ A significant difference was observed between E. coli PGDH without serine and E. coli PGDH in the presence of $60 \mathrm{mM}, 120 \mathrm{mM}, 240 \mathrm{mM}, 480 \mathrm{mM}$, and $960 \mathrm{mM}$ serine $\left.{ }^{*} \mathrm{P}<0.05\right)$. c A significant difference was not observed between human PGDH without serine and human PGDH in the presence of $1 \mathrm{mM}, 10 \mathrm{mM}$, and $100 \mathrm{mM}$ serine (ns)
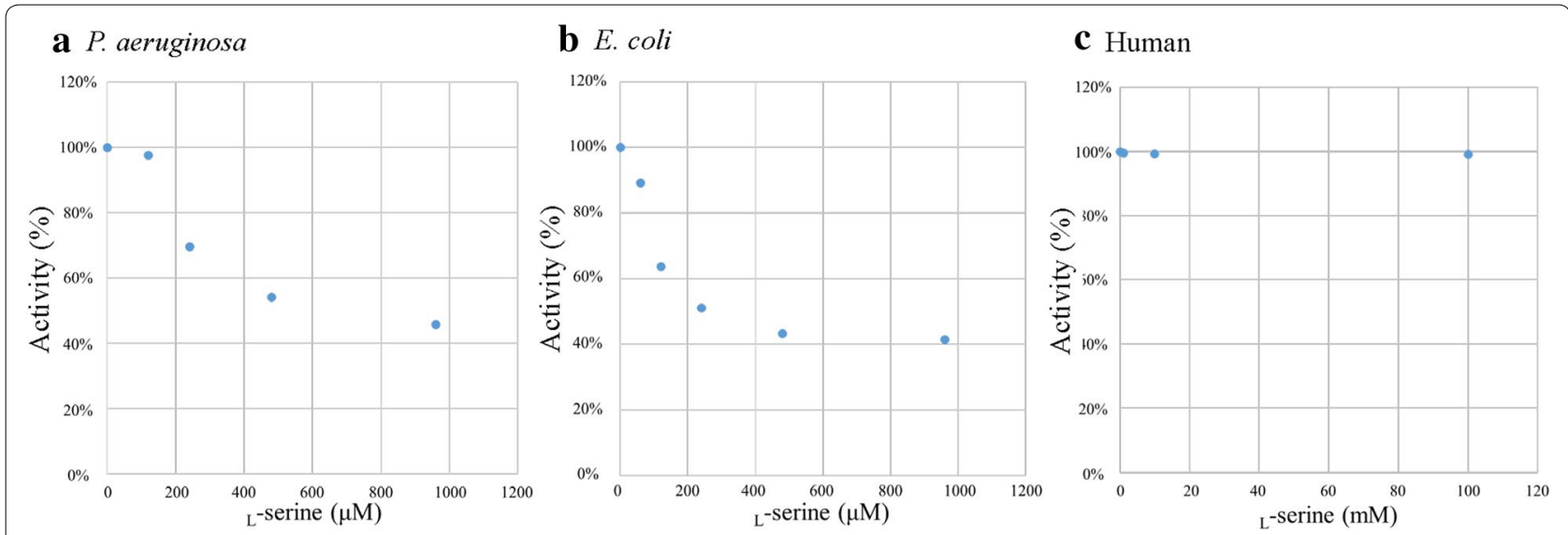

Fig. 6 A graph plot shows for the PGDH activity (\%) and the L-serine concentrations. The $50 \%$ inhibitory concentration (IC $\left.C_{50}\right)$ of L-serine was calculated from data shown in Fig. 5. The PGDH activity of P. aeruginosa (a), that of E. coli (b) and the human PGDH activity (c)

glycine, L-alanine, L-cystine, and L-homoserine on the $E$. coli PGDH activity was evaluated, and it was found that $\mathrm{L}$-serine had the lowest $\mathrm{IC}_{50}$ value among other amino acids .

\section{Conclusions}

We previously reported that the inhibition of the serA gene by $\mathrm{L}$-serine caused significant reduction in the bacterial penetration through the Caco- 2 cell monolayers, bacterial swarming and swimming motilities, bacterial 


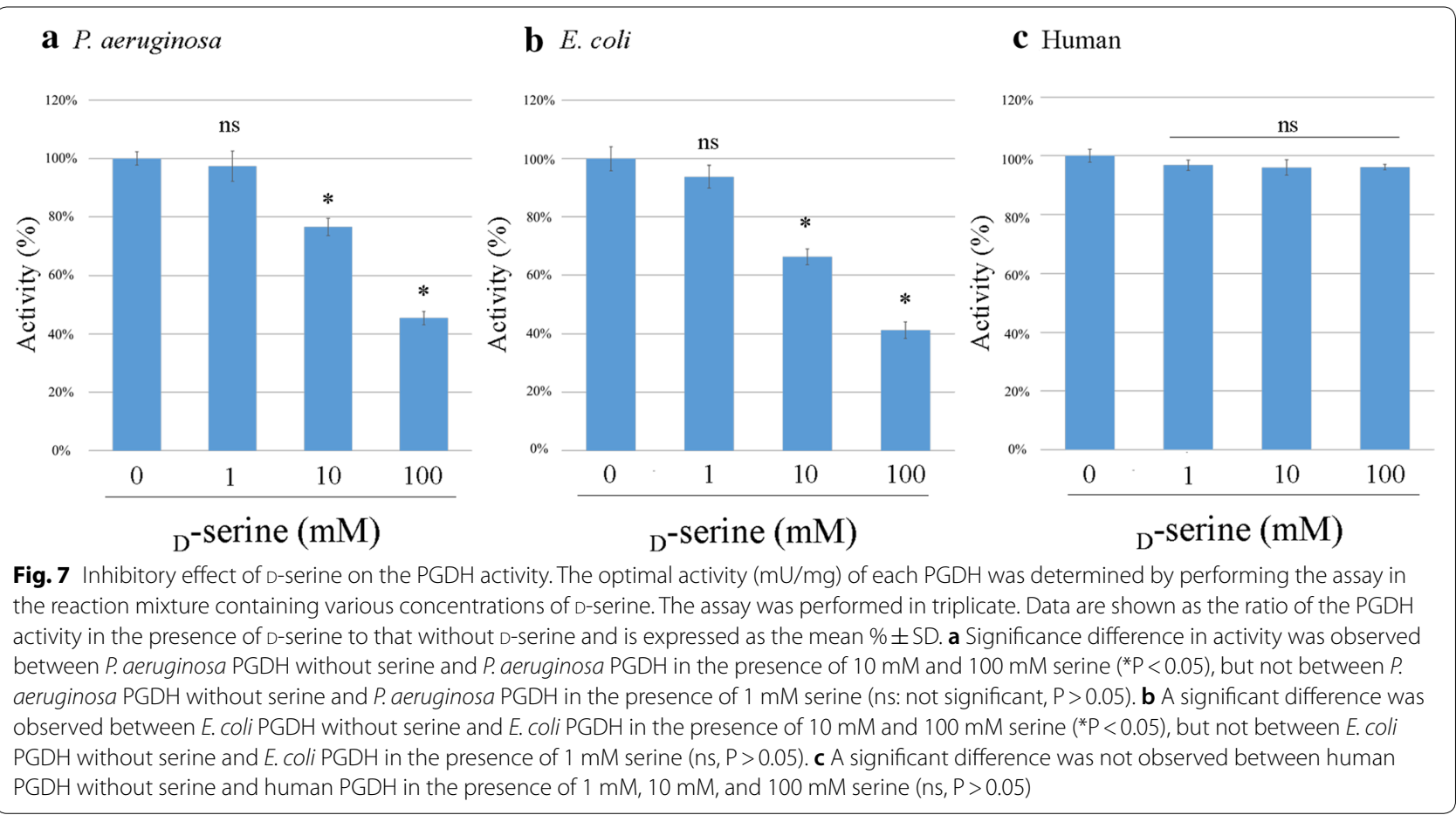
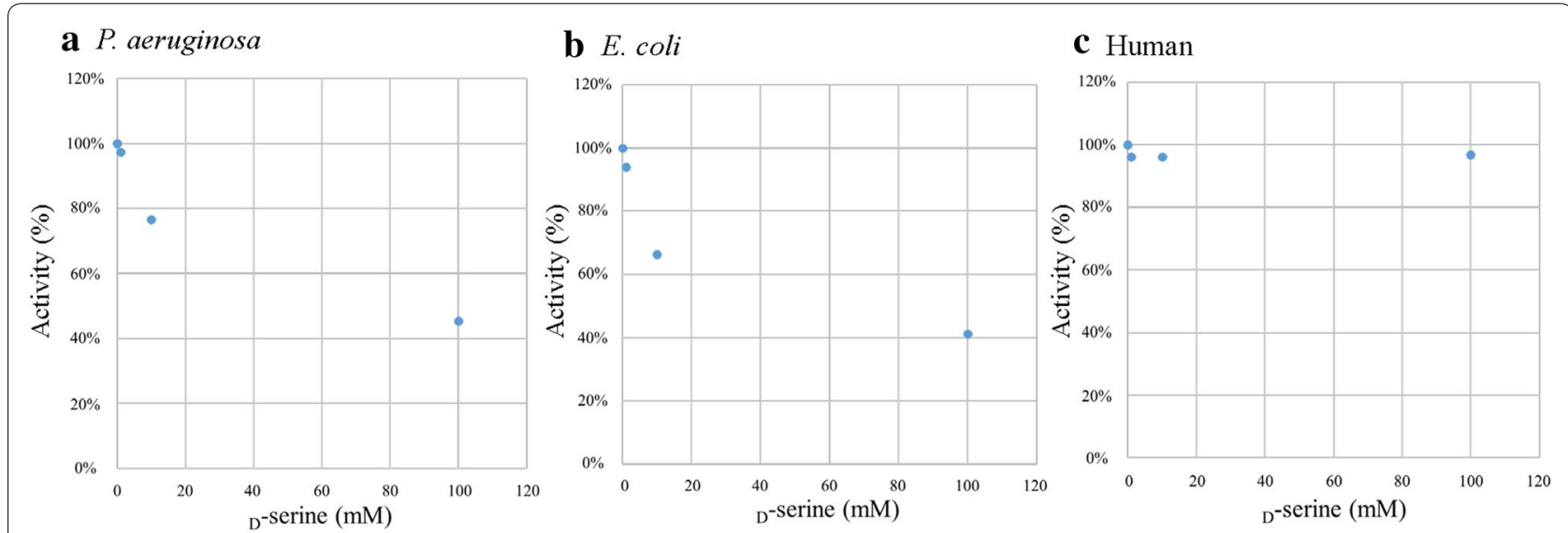

Fig. 8 A graph plot shows for the PGDH activity (\%) and the D-serine concentrations. The 50\% inhibitory concentration (IC $\left.C_{50}\right)$ of D-serine was calculated from the data shown in Fig. 7. The PGDH activity of P. aeruginosa (a), that of E. coli (b) and the human PGDH activity (c)

adherence to Caco-2 cells, and virulence in flies in the wild-type $P$. aeruginosa PAO1 strain. Oral administration of $\mathrm{L}$-serine to the compromised hosts, through the inhibition of serA function, might have the potential to prevent the bacterial infection and septicemia caused by $P$. aeruginosa [1]. Here, we showed that L-serine inhibits the activity of PGDH from P. aeruginosa PAO1 strain, while L-serine did not affect the activity of human PGDH even at 159-fold higher concentration (100 mM) when compared with $\mathrm{IC}_{50}$ value of L-serine against $P$. aeruginosa PGDH $(630 \mu \mathrm{M})$ (Figs. 5, 6). Overall, our data suggest that the oral administration of $\mathrm{L}$-serine to the compromised human hosts might have the potential to interfere with the bacterial translocation and prevent the septicemia caused by $P$. aeruginosa through the inhibition of PGDH activity of SerA protein.

Acknowledgements

Not applicable. 


\section{Authors' contributions}

JO, SN, MY, and CS developed the design and concept of the study. JO, MY, and CS provided technical advice. SN, MY, and KI carried out the PGDH activity assays. JO analyzed and interpreted the data. JO drafted and revised the manuscript. All authors read and approved the final manuscript.

\section{Funding}

Not applicable.

\section{Availability of data and materials}

All data generated for this study are included in the published article.

\section{Ethics approval and consent to participate}

Not applicable.

\section{Consent for publication}

Not applicable.

\section{Competing interests}

The authors declare that they have no competing interests.

Received: 27 March 2019 Accepted: 21 June 2019

Published online: 30 June 2019

\section{References}

1. Yasuda M, Nagata S, Yamane S, Kunikata C, Kida Y, Kuwano K, et al. Pseudomonas aeruginosa serA gene is required for bacterial translocation through Caco-2 cell monolayers. PLoS ONE. 2017;12:e0169367.

2. Pizer L. The pathway and control of serine biosynthesis in Escherichia coli. J Biol Chem. 1963;238:3934-44.

3. Wang Q, Qi Y, Yin N, Lai L. Discovery of novel allosteric effectors based on the predicted allosteric sites for Escherichia coli D-3-phosphoglycerate dehydrogenase. PLOS ONE. 2014:9:e94829.

4. Walsh DA, Sallach HJ. Purification and properties of chicken liver D-3-phosphoglycerate dehydrogenase. Biochemistry. 1965;4:1076-85.

5. Achouri Y, Rider MH, Schaftingen EV, Robbi M. Cloning, sequencing and expression of rat liver 3-phosphoglycerate dehydrogenase. Biochem J. 1997:323:365-70

6. Dey S, Hu Z, Xu XL, Sacchettini JC, Grant GA. D-3-Phosphoglycerate dehydrogenase from Mycobacterium tuberculosis is a link between the Escherichia coli and mammalian enzymes. J Biol Chem. 2005;280:14884-91.

7. Grant GA. Contrasting catalytic and allosteric mechanisms for phosphoglycerate dehydrogenases. Arch Biochem Biophys. 2012;519:175-85.

8. Grant GA. D-3-phosphoglycerate dehydrogenase. Front Mol Biosci. 2018:5:110.

9. Chipman D, Shaanan B. The ACT domain family. Curr Opin Struct Biol. 2001;11:694-700.

10. Unterlass JE, Wood RJ, Baslé A, Tucker J, Cano C, Noble MME, et al. Structural insights into the enzymatic activity and potential substrate promiscuity of human 3-phosphoglycerate dehydrogenase (PHGDH). Oncotarget. 2017;8:104478-91.

11. Kishore V, Nishita KP, Manonmani HK. Cloning, expression and characterization of L-asparaginase from Pseudomonas fluorescens for large scale production in E. coli BL21. 3 Biotech. 2015;5:975-81.

12. Kaelin WG, Krek W, Sellers WR, DeCaprio JA, Ajchenbaum F, Fuchs CS, et al. Expression cloning of a cDNA encoding a retinoblastoma-binding protein with E2F-like properties. Cell. 1992;70:351-64.

13. Peters-Wendisch P, Netzer R, Eggeling L, Sahm H. 3-Phosphoglycerate dehydrogenase from Corynebacterium glutamicum: the C-terminal domain is not essential for activity but is required for inhibition by L-serine. Appl Microbiol Biotechnol. 2002;60:437-41.

14. Vynohradova RP. Units of enzyme activity. Ukr Biokhim Zh. 1999;71:96-9.

15. Gillard BK, Marksman HC, Feig SA. Direct spectrophotometric determination of alpha-amylase activity in salive, with p-nitrophenyl alpha-maltoside as substrate. Clin Chem. 1977;23:2279-82.

16. Tabatabaie L, Koning TJ, Geboers AJ, Berg IE, Berger R, Klomp LWJ. Novel mutations in 3-phosphoglycerate dehydrogenase (PHGDH) are distributed throughout the protein and result in altered enzyme kinetics. Hum Mutat. 2009:30:749-56.

17. Pind S, Slominski E, Mauthe J, Pearlman K, Swoboda KJ, Wilkins JA, et al. V490 M, a common mutation in 3-phosphoglycerate dehydrogenase deficiency, causes enzyme deficiency by decreasing the yield of mature enzyme. J Biol Chem. 2002;277:7136-43.

18. Achouri Y, Rider MH, Schaftingen EV, Robbi M. Cloning, sequencing and expression of rat liver 3-phosphoglycerate dehydrogenase. Biochem J. 1997;323(Pt 2):365-70.

19. Jaeken J, Detheux M, Van Maldergem L, Foulon M, Carchon H, Van Schaftingen E. 3-Phosphoglycerate dehydrogenase deficiency: an inborn error of serine biosynthesis. Arch Dis Child. 1996;74:542-5.

20. Grant $G A, X u X L, H u Z$. Role of an interdomain Gly-Gly sequence at the regulatory-substrate domain interface in the regulation of Escherichia coli D-3-phosphoglycerate dehydrogenase. Biochemistry. 2000;39:7316-9.

21. Al-Rabiee R, Zhang Y, Grant GA. The mechanism of velocity modulated allosteric regulation in D-3-phosphoglycerate dehydrogenase. Sitedirected mutagenesis of effector binding site residues. J Biol Chem. 1996; 271:23235-8.

22. Grant GA, Schuller DJ, Banaszak LJ. A model for the regulation of D-3-phosphoglycerate dehydrogenase, a Vmax-type allosteric enzyme. Protein Sci. 1996;5:34-41.

23. Tobey KL, Grant GA. The nucleotide sequence of the serA gene of Escherichia coli and the amino acid sequence of the encoded protein, D-3-phosphoglycerate dehydrogenase. J Biol Chem. 1986;261:12179-83.

\section{Publisher's Note}

Springer Nature remains neutral with regard to jurisdictional claims in published maps and institutional affiliations.

Ready to submit your research? Choose BMC and benefit from

- fast, convenient online submission

- thorough peer review by experienced researchers in your field

- rapid publication on acceptance

- support for research data, including large and complex data types

- gold Open Access which fosters wider collaboration and increased citations

- maximum visibility for your research: over 100M website views per year

At $\mathrm{BMC}$, research is always in progress.

Learn more biomedcentral.com/submissions 